\title{
Rivaroxaban plasma levels in patients admitted for bleeding events: insights from a prospective study
}

Anne-Laure Sennesael ${ }^{1,3^{*}}$ D, Anne-Sophie Larock ${ }^{2}$, Jonathan Douxfils ${ }^{3}$, Laure Elens ${ }^{4}$, Gabriel Stillemans ${ }^{4}$, Martin Wiesen ${ }^{5}$, Max Taubert ${ }^{6}$, Jean-Michel Dogné ${ }^{3}$, Anne Spinewine $^{1,2}$ and François Mullier ${ }^{7}$

\begin{abstract}
Background: Serious bleeding events have been frequently described in patients taking direct oral anticoagulants (DOAC). In secondary analyses of phase 3 trials, DOAC plasma concentrations were shown to correlate with bleeding outcomes. This study aimed to describe rivaroxaban plasma levels in patients admitted to the emergency department (ED) for bleeding events. For each patient, risk factors for experiencing bleeding events were also investigated.

Methods: This analysis was part of an observational study conducted in the ED of two teaching hospitals. Plasma samples from 10 rivaroxaban-treated patients admitted for bleeding events were collected. Rivaroxaban plasma concentrations were determined by calibrated chromogenic anti-Xa assay. The measured rivaroxaban levels were then extrapolated at trough using a published population pharmacokinetic (PopPK) model, and compared to ontherapy ranges observed in large clinical trials. For each patient, clinical, medication and $A B C B 1$ genotype data were collected.
\end{abstract}

Results: Rivaroxaban measurements varied from 5 to $358 \mathrm{ng} / \mathrm{ml}$, with a post-intake delay ranging from 9 to $38 \mathrm{~h}$. At trough, estimated plasma concentrations were between 12 and $251 \mathrm{ng} / \mathrm{ml}$ (median value $94 \mathrm{ng} / \mathrm{ml}$ ). Four patients had higher-than-expected rivaroxaban levels. Inadequate dose regimen, excessive alcohol consumption and lack of treatment reassessment were observed in several patients. Half of patients were taking $\geq 1$ drug with potential pharmacokinetics interactions (e.g. amiodarone, diltiazem), while half of patients were taking $\geq 1$ drug increasing the risk of bleeding. All 3 patients with available genotyping data and higher-than-expected rivaroxaban levels were heterozygous or homozygous mutated for the ABCB1 1236C > T, 2677G > T, 3435 C > T and rs4148738 single nucleotide polymorphisms (SNP).

Conclusions: Rivaroxaban patients admitted to the ED for bleeding events showed highly variable plasma concentrations. This analysis underlines the usefulness of rapid DOAC measurement and the value of PopPK models to estimate concentrations at trough in a context where the post-intake delay is unmanageable. Close patient follow-up, including renal function assessment and drug interactions review, is essential for bleeding risk minimization.

Keywords: Direct oral anticoagulants, Rivaroxaban, Bleeding, Drug monitoring, Pharmacogenomics, Patient safety

\footnotetext{
* Correspondence: anne-laure.sennesael@uclouvain.be

${ }^{1}$ Louvain Drug Research Institute, Clinical Pharmacy Research Group,

Université catholique de Louvain, Brussels, Belgium

${ }^{3}$ Namur Research Institute for LIfe Sciences, Namur Thrombosis and

Hemostasis Center, Department of Pharmacy, University of Namur, Namur,

Belgium

Full list of author information is available at the end of the article
}

(C) The Author(s). 2018 Open Access This article is distributed under the terms of the Creative Commons Attribution 4.0 International License (http://creativecommons.org/licenses/by/4.0/), which permits unrestricted use, distribution, and reproduction in any medium, provided you give appropriate credit to the original author(s) and the source, provide a link to the Creative Commons license, and indicate if changes were made. The Creative Commons Public Domain Dedication waiver (http://creativecommons.org/publicdomain/zero/1.0/) applies to the data made available in this article, unless otherwise stated. 


\section{Background}

Direct oral anticoagulants (DOAC) are increasingly used in clinical practice, to prevent venous thrombosis or thrombus formation in non-valvular atrial fibrillation $[1,2]$. However, serious bleeding events have been frequently described for patients taking DOACs. In 20132014, rivaroxaban and dabigatran were among the drugs most commonly implicated in emergency department (ED) admissions in the United States [3]. During phase 3 trials, risk of major bleeding of DOACs was similar to or lower than warfarin, whereas the risk of intracranial hemorrhage was substantially reduced $[4,5]$. Recent observational studies have shown similar results in a real-life setting [6].

Although DOACs do not require close therapeutic monitoring, their measurement remains useful in specific clinical situations such as major bleeding and emergency surgery [7]. Assessment of the individual response may also benefit patients with suspected drug accumulation or therapeutic failure. In secondary analyses of phase 3 trials, DOAC plasma concentrations were shown to correlate with bleeding outcomes [8-10]. Conversely, a recent observational study has highlighted the relationship between low DOAC levels, measured in the first month of treatment, and the occurrence of thromboembolic events [11]. However, a therapeutic range has not been defined yet for each DOAC.

To our knowledge, few studies have investigated the intensity of DOAC anticoagulation in patients presenting to the ED for bleeding events. In the RE-VERSE AD study, the median (unbound) dabigatran plasma concentration was $110 \mathrm{ng} / \mathrm{ml}$ in patients with uncontrollable or life-threatening bleeding, before the administration of idarucizumab [12]. Bouget and Oger described DOAC levels in 5 patients admitted for major bleeding [13]. However, measurements were not interpreted by taking into account the post-intake delay and other influencing individual factors.

In this study, we aimed to describe rivaroxaban levels in patients admitted to the ED for bleeding events. Measured plasma concentrations were extrapolated at trough using population pharmacokinetic (popPK) modeling, and compared to the expected on-therapy range. Several determinants of bleeding were previously reported in rivaroxaban-treated patients, including older age, renal impairment or drug interactions [14-17]. The inappropriate use of DOAC has also been highlighted in this respect $[18,19]$. In addition, $A B C B 1$ genetic polymorphisms have recently been suggested to contribute to high rivaroxaban levels in a patient admitted for gastrointestinal bleeding [20]. Therefore, a second objective was to investigate and discuss the presence of such risk factors for bleeding events in our rivaroxaban patients.

\section{Methods}

\section{Setting and population}

This analysis was part of a prospective observational cohort study, conducted in two teaching hospitals in Belgium to assess the preventability of serious adverse drug reactions related to the use of oral anticoagulants [21]. We collected plasma samples from rivaroxaban patients admitted to the ED for a bleeding event, between July 2015 and January 2016.

\section{Rivaroxaban measurement}

Blood sampling was performed closely after management and inclusion of the patient in the study. Blood was taken by antecubital venipuncture and collected into $0.109 \mathrm{M}$ sodium citrate $(9: 1 \mathrm{v} / \mathrm{v})$ tubes. Platelet-poor plasma (PPP) was obtained from the supernatant fraction after double centrifugation for $15 \mathrm{~min}$ at $1500 \mathrm{~g}$ at room temperature. PPP was next aliquoted and frozen at $-80{ }^{\circ} \mathrm{C}$ without delay. Frozen plasma samples aliquots were thawed by heating to $37{ }^{\circ} \mathrm{C}$ for at least 5 min just before experiments.

The following routine clotting assay was performed: prothrombin time (PT) using RecombiPlasTin2G ${ }^{\odot}$ (Werfen, Lexington, USA; normal range 12.4-14.5 s). Rivaroxaban plasma concentrations were estimated with the Biophen ${ }^{\circ}$ Direct Factor Xa Inhibitors (Biophen DiXaI, Hyphen BioMed, Neuville-Sur-Oise, France), a calibrated chromogenic anti-Xa assay. The procedure was performed on a STA- $\mathrm{R}^{\bullet}$ Evolution analyzer according to the manufacturer recommendations, using calibrators from Hyphen BioMed. Commercial rivaroxaban anti-Xa assays have previously demonstrated good accuracy (bias below 8\%) and acceptable precision (inter-laboratory coefficients of variation (CV) 6-25\%) [22]. A procedure dedicated to low concentrations was applied to rivaroxaban plasma concentrations $<50 \mathrm{ng} / \mathrm{ml}$, where plasma samples were diluted 1:8 in buffer and low concentrations standards were used [23].

We extrapolated rivaroxaban plasma concentrations at trough (i.e. $12 \mathrm{~h}$ and $24 \mathrm{~h}$ after the last drug intake for twice daily and once daily regimen, respectively). To this end, we used a Pop PK model that was previously developed to predict adequate discontinuation intervals in a cohort of rivaroxaban patients scheduled for cardiac catheterization [24]. Residual rivaroxaban concentrations were described by a 2-compartment model with first-order absorption and elimination. Results were then compared to the expected on-therapy ranges at trough (5th-95th percentiles): $12-137 \mathrm{ng} / \mathrm{ml}$ (rivaroxaban $20 \mathrm{mg}$ ) and 18$136 \mathrm{ng} / \mathrm{ml}$ (rivaroxaban $15 \mathrm{mg}$ ) for stroke prevention in non-valvular atrial fibrillation (NVAF), and 6-87 ng/ml for treatment and secondary prevention of venous thromboembolism (VTE) [25]. 


\section{Data collection}

A comprehensive medication history was performed with patients and/or relatives to collect sociodemographic, clinical and medication data (including dose regimen, indication and timing of the last rivaroxaban intake). Patient renal function was estimated based on serum creatinine on admission using Cockroft-Gault equation. We reviewed electronic medical records and contacted GPs, community pharmacists or relatives when necessary. Bleeding severity was assessed using the International Society on Thrombosis and Haemostasis definition. Patient follow-up was undertaken to assess 3-month mortality.

Appropriateness of rivaroxaban prescribing was analyzed according to the Medication Appropriateness Index (MAI) [26]. We applied a DOAC-specific form, previously developed in a pilot study [27]. We documented the concomitant use of P-glycoprotein (P-gp) and CYP3A4 inhibitors or inducers. Regarding potential pharmacodynamics interactions, we considered other anticoagulants, antiplatelet therapy, non-steroidal anti-inflammatory drugs (NSAID), selective serotonin reuptake inhibitors (SSRI) and serotonin-norepinephrine reuptake inhibitors (SNRI). Patient adherence to anticoagulant therapy was evaluated during medication history using an adapted version of the Morisky Medication Adherence Scale [28].

\section{$A B C B 1$ genetic polymorphisms}

For all patients except one (because of misunderstanding), an additional blood sample was drawn in EDTA tube and frozen at $-20{ }^{\circ} \mathrm{C}$ without delay until experiments. Genomic DNA was extracted from whole blood, using QIAamp DNA Blood Mini kit (Qiagen, CA, USA). The following single nucleotide polymorphisms (SNP) of $A B C B 1$ were detected: rs1128503 (1236C > T, Gly412Gly), rs2032582 (2677G > T, Ala893Ser), rs1045642 (3435 C > T, Ile1145Ile) and rs4148738. Allelic discrimination was performed by
TaqMan $^{\oplus}$ (Applied Biosystems, CA, USA) Drug Metabolism Genotyping Assays (C_7586662_10, C_11711720C_30, C_15951365_20, C__1253813_10). Statistical analyses were performed using JMP Pro 13.2.0 (SAS Institute, Cary, NC, USA). Kruskal-Wallis tests were carried out to compare estimated trough concentrations between different genotypes. A $p$-value of less than 0.05 was considered statistically significant.

\section{Results}

\section{Study population}

Plasma samples from 10 rivaroxaban patients were included in this analysis. Median age of patients was 75 years, and $80 \%$ were female. Five patients had moderate renal impairment on admission (creatinine clearance $<60 \mathrm{ml} / \mathrm{min}$ ). Indications of rivaroxaban therapy were stroke prevention in NVAF (6/10) and treatment and secondary prevention of VTE (4/10). Clinical characteristics are detailed in Table 1 for each patient. The most frequent adverse events were gastrointestinal bleeding (4/10). Half of bleeding events were considered major and half occurred spontaneously. Red blood cells transfusion and prothrombin complex concentrates administration were operated in 4 and 1 patients, respectively. All patients were alive at 3-month follow-up. Details of bleeding events are presented in Table 2.

\section{Rivaroxaban measurement}

Measured rivaroxaban levels varied from 5 to $358 \mathrm{ng} / \mathrm{ml}$, with a delay since the last drug intake ranging from 9 to $38 \mathrm{~h}$. PT was above the normal range in all patients with rivaroxaban concentrations above $30 \mathrm{ng} / \mathrm{ml}$ (Table 3). When using PopPK model, estimated plasma concentrations at trough were between 12 and $251 \mathrm{ng} / \mathrm{ml}$ (median value $94 \mathrm{ng} / \mathrm{ml})$. Elimination clearance $(\mathrm{CL} / \mathrm{F})$ was between 2.0 and $7.9 \mathrm{~L} / \mathrm{h}$ (median value $3.3 \mathrm{~L} / \mathrm{h}$ ). Measured and extrapolated rivaroxaban concentrations are described

Table 1 Characteristics of rivaroxaban patients

\begin{tabular}{|c|c|c|c|c|c|c|c|c|c|c|}
\hline No & $\begin{array}{l}\text { Sex, age } \\
\text { (years) }\end{array}$ & $\begin{array}{l}\text { Weight } \\
(\mathrm{kg})\end{array}$ & $\begin{array}{l}\text { BMI } \\
\left(\mathrm{kg} / \mathrm{m}^{2}\right)\end{array}$ & $\begin{array}{l}\text { CLCr } \\
(\mathrm{ml} / \mathrm{min})\end{array}$ & $\begin{array}{l}\mathrm{Hb} \\
(\mathrm{g} / \mathrm{dl})\end{array}$ & Indication & Dosage & Duration & $\mathrm{CHA}_{2} \mathrm{DS}_{2}-\mathrm{VASC}$ & HAS-BLED \\
\hline 1 & $M, 83$ & 79 & 23.1 & 58 & 13.7 & SPAF & $20 \mathrm{mg}$ OD & $\leq 1$ year & 5 & 3 \\
\hline 2 & $F, 70$ & $\mathrm{~N} / \mathrm{K}$ & $N / K$ & $\mathrm{~N} / \mathrm{K}$ & 3.1 & SPAF & $15 \mathrm{mg}$ OD & $>1$ year & 3 & 1 \\
\hline 3 & $F, 87$ & 65 & 25.7 & 48 & 6.4 & VTE & $20 \mathrm{mg}$ OD & $<30$ days & N/A & 2 \\
\hline 4 & $F, 67$ & 80 & 24.7 & 53 & 7.2 & SPAF & $20 \mathrm{mg} \mathrm{OD}$ & $>1$ year & 6 & 2 \\
\hline 5 & $F, 77$ & 63 & 25.2 & 61 & 14.3 & SPAF & $15 \mathrm{mg}$ OD & $>1$ year & 7 & 3 \\
\hline 6 & $M, 66$ & 100 & 35 & 86 & 15.6 & SPAF & $20 \mathrm{mg} O \mathrm{OD}$ & $\leq 1$ year & 2 & 2 \\
\hline 7 & $F, 72$ & 66 & 21.6 & 46 & 12.8 & VTE & $20 \mathrm{mg} \mathrm{OD}$ & $>1$ year & $\mathrm{N} / \mathrm{A}$ & 3 \\
\hline 8 & $F, 90$ & 70 & $\mathrm{~N} / \mathrm{K}$ & 60 & 13.8 & SPAF & $15 \mathrm{mg} \mathrm{OD}$ & $\mathrm{N} / \mathrm{K}$ & 6 & 1 \\
\hline 9 & $F, 86$ & 89 & 31.2 & 57 & 14.9 & VTE & $15 \mathrm{mg}$ BID & $<30$ days & N/A & 1 \\
\hline 10 & $F, 69$ & 73 & 26.8 & 76 & 11.3 & VTE & $20 \mathrm{mg}$ OD & $>1$ year & $\mathrm{N} / \mathrm{A}$ & 2 \\
\hline
\end{tabular}


Table 2 Characteristics, management and clinical outcomes of the 10 bleeding events

\begin{tabular}{lllllll}
\hline No & Site of bleeding & Bleeding severity & Bleeding occurrence & Management & Length of stay (days) & 90-day outcome \\
\hline 1 & Hematuria & NMCR & Trauma & - & 0 & Alive \\
2 & Gastrointestinal & Major & Spontaneous & RBC (3 units) & N/K & Alive \\
3 & Gastrointestinal & Major & Spontaneous & RBC (2 units) & 3 & Alive \\
4 & Gastrointestinal & Major & Spontaneous & RBC (3 units) & 1 & Alive \\
5 & Intracranial & Major & Trauma & PCC (2500 IU) & 43 & Alive \\
6 & Gastrointestinal & NMCR & Post-intervention & - & 0 & Alive \\
7 & Epistaxis & NMCR & Spontaneous & - & 2 & Alive \\
8 & Intracranial & Major & Trauma & - & 1 & Alive \\
9 & Hematuria & NMCR & Spontaneous & - & 0 & N/K \\
10 & Hematoma & NMCR & Trauma & - & 0 & . \\
\hline
\end{tabular}

N/K not known, NMCR non-major clinically relevant, $P C C$ prothrombin complex concentrates, $R B C$ red blood cells. ${ }^{\mathrm{a}}$ Transfusion before blood sampling

in Table 3 for each patient, as well as the elimination clearance. Four patients had rivaroxaban levels at trough higher than the expected on-therapy range (No 2, 3, 5, 9).

\section{Analysis of risk factors for bleeding events}

The analysis of rivaroxaban prescriptions revealed that at least one criterion of the MAI was inappropriate in 8 of 10 patients. Three patients received an inadequate dosing regimen: $20 \mathrm{mg}$ OD instead of $15 \mathrm{mg}$ OD (No 3, 7), and $15 \mathrm{mg}$ BID instead of $20 \mathrm{mg}$ OD (No 9). Two of them had estimated trough concentration above the on-therapy range. Three patients had an excessive alcohol consumption ( $\geq 2$ units/day; No $1,4,7)$. Moreover, in two patients treated for VTE prevention, treatment indication had not been reassessed for years (No 3, 10).

Half of patients were taking at least 1 drug with potential pharmacokinetic interactions (Table 3). Three of them had higher-than-expected rivaroxaban plasma concentrations at trough. The most frequent interacting drugs were amiodarone and diltiazem. Moreover, half of patients were taking at least 1 drug increasing the risk of bleeding (Table 3 ). We mainly observed the concomitant use of SSRI $(n=3)$ and NSAID $(n=2)$. Regarding adherence to anticoagulant therapy, three patients reported forgetting to take their medicine in rare circumstances (No 1, 4, 7). One patient mentioned a variable time of intake (No 7).

$A B C B 1$ genetic polymorphisms were analyzed in 9 of 10 patients. Genotyping data are presented in Table 4 for the $A B C B 11236 \mathrm{C}>\mathrm{T}, 2677 \mathrm{G}>\mathrm{T}, 3435 \mathrm{C}>\mathrm{T}$ and rs4148738 SNP. Of the four patients with higher-than-expected rivaroxaban trough levels, three carried at least one variant allele for each of these SNP (No 2, 3, 5 - blood sample not available for patient No 9). However, no clear association between ABCB1 genotype and estimated trough concentrations was observed $(p>0.05)$.

Table 3 Measurement of rivaroxaban plasma concentrations

\begin{tabular}{|c|c|c|c|c|c|c|c|}
\hline No & Delay (h) & PT (sec) & Biophen $^{\oplus}$ DiXal $(\mathrm{ng} / \mathrm{ml})$ & $\begin{array}{l}\text { Estimated } \mathrm{cc} \text { at } \\
\text { trough }(\mathrm{ng} / \mathrm{ml})\end{array}$ & $\begin{array}{l}\text { Clearance } \\
(\mathrm{L} / \mathrm{h})\end{array}$ & $\begin{array}{l}\text { Potential PK drug } \\
\text { interactions }\end{array}$ & $\begin{array}{l}\text { Potential PD drug } \\
\text { interactions }\end{array}$ \\
\hline 1 & 28 & 18.7 & 84.8 & 98 & 3.3 & - & Ibuprofen \\
\hline 2 & 22 & 19.6 & 237.5 & $181^{a}$ & 2.0 & Diltiazem $(\uparrow)$, Clarithromycin $(\uparrow)$ & Escitalopram \\
\hline 3 & 38 & 15.4 & 70.8 & $125^{\mathrm{a}}$ & 2.9 & Simvastatin $(\uparrow)$ & / \\
\hline 4 & 27 & 17.7 & 58.3 & 69 & 3.9 & - & Diclofenac, Escitalopram \\
\hline 5 & 27 & $N / K$ & 139.4 & $134^{\mathrm{a}}$ & 2.4 & Amiodarone $(\uparrow)$ & Aspirin \\
\hline 6 & 26 & 12.9 & 4.9 & 12 & 7.9 & Amiodarone $(\uparrow)$ & / \\
\hline 7 & 37 & 14.4 & 18.3 & 44 & 4.8 & Diltiazem $(\uparrow)$ & / \\
\hline 8 & 27 & 15.3 & 86.5 & 89 & 3.0 & / & / \\
\hline 9 & 9 & 26.0 & 357.8 & $251^{\mathrm{a}}$ & 3.2 & / & / \\
\hline 10 & 13 & $N / K$ & 184.7 & 72 & 3.9 & / & Duloxetine, Paroxetine \\
\hline
\end{tabular}

Biophen ${ }^{\circledR}$ DiXal Biophen ${ }^{\oplus}$ Direct Factor Xa Inhibitors, $c c$ concentration, N/K not known, $P D$ pharmacodynamics, $P K$ pharmacokinetics, $P T$ prothrombin time (normal range: 12.4-14.5 s), $\uparrow$ : increased plasma concentrations, $\downarrow$ : decreased plasma concentrations

${ }^{a}$ Estimated trough concentration above the on-therapy range (we considered higher-than-expected rivaroxaban levels for patient 5, as measured concentration was higher than $136 \mathrm{ng} / \mathrm{ml}$ ) 
Table $4 A B C B 1$ genotyping in 10 rivaroxaban patients with bleeding events

\begin{tabular}{|c|c|c|c|c|}
\hline No & $1236 \mathrm{C}>\mathrm{T}$ & $2677 \mathrm{G}>\mathrm{T}$ & $3435 C>T$ & rs4148738 \\
\hline 1 & $C C$ & GG & $\mathrm{CC}$ & AA \\
\hline 2 & $\mathrm{CT}$ & GT & $\mathrm{CT}$ & GA \\
\hline 3 & CT & GT & $\mathrm{CT}$ & GA \\
\hline 4 & $\Pi$ & $\pi$ & $\mathrm{CT}$ & GG \\
\hline 5 & CT & GT & $\mathrm{TT}$ & $\mathrm{GA}$ \\
\hline 6 & $\Pi$ & $\pi$ & $\pi$ & GG \\
\hline 7 & $\mathrm{CT}$ & GT & $\pi$ & $\mathrm{GA}$ \\
\hline 8 & $\Pi$ & $\Pi$ & $\pi$ & GG \\
\hline 9 & $\mathrm{~N} / \mathrm{K}$ & $\mathrm{N} / \mathrm{K}$ & $\mathrm{N} / \mathrm{K}$ & $\mathrm{N} / \mathrm{K}$ \\
\hline 10 & CC & GG & CT & AA \\
\hline
\end{tabular}

$\mathrm{N} / \mathrm{K}$ not known. Patients with higher-than-expected rivaroxaban levels are shown in bold

\section{Discussion}

In this analysis of 10 patients admitted for bleeding events, we observed a large range of rivaroxaban levels. The application of a previously published PopPK model revealed that four patients had higher-than-expected plasma concentrations at trough. Several risk factors for bleeding were found at the individual level, including older age, inappropriate use of rivaroxaban and drug interactions.

To our knowledge, this is the first study to analyze in depth rivaroxaban measurements in the context of bleeding events. Inter-individual variability in DOAC exposure has been previously investigated in routine care, showing plasma levels outside the on-therapy range in $40 \%$ of rivaroxaban patients [29]. In four Italian anticoagulation clinics, rivaroxaban measurements varied nearly 15-fold among NVAF patients, with a mean trough level around $40 \mathrm{ng} / \mathrm{ml}$ [30]. This variability is in agreement with our results, although we estimated a higher median trough concentration $(94 \mathrm{ng} / \mathrm{ml})$. This reflects a delayed rivaroxaban clearance in our bleeding patients (median CL/F $3.3 \mathrm{~L} / \mathrm{h}$, compared to $4.9 \mathrm{~L} / \mathrm{h}$ in patients scheduled for cardiac catheterization or $6.1 \mathrm{~L} / \mathrm{h}$ in $\mathrm{AF}$ patients as previously reported) $[24,31]$. Two recent cohort studies have shown median rivaroxaban levels of $124 \mathrm{ng} / \mathrm{ml}$ in patients with severe bleeding events, and $102 \mathrm{ng} / \mathrm{ml}$ in patients admitted for intracranial hemorrhage [32, 33]. Delay since the last drug intake was $12 \mathrm{~h}$ (median value) in the former case, and less than $24 \mathrm{~h}$ for most patients in the latter case.

\section{Rivaroxaban measurement for bleeding management}

The management of DOAC-related bleeding includes the temporary discontinuation of the oral anticoagulant, supportive measures and the administration of reversal agents, depending on the severity of the event [34, 35]. Andexanet alpha has recently been approved by the
FDA to reverse the anticoagulant effect of rivaroxaban, while prothrombin complex concentrates were also suggested as an alternative [36-38]. In this context, rapid laboratory measurement may provide valuable assistance to warrant and monitor antidote administration, or manage urgent interventions [7].

In the present study, we observed that PT was prolonged in all patients with clinically relevant concentrations $(>30 \mathrm{ng} / \mathrm{ml})$ of rivaroxaban. However, we employed a sensitive thromboplastin reagent (RecombiPlasTin $2 G^{\circ}$ ) for the assay [39]. A nationwide Belgian survey has previously highlighted a wide variation in response to rivaroxaban according to the reagent used [40]. Commercial specific assays are currently available for all DOACs [41]. They are more accurate but require calibrators and controls. Turnaround times around $30 \mathrm{~min}$ have nevertheless been reported in a daily practice context $[42,43]$.

\section{Factors associated with an increased risk of bleeding}

Several risk factors for bleeding events were highlighted in our 10 rivaroxaban patients. First, half of them were older than 75 years, and half of them had moderate renal impairment. Older age and renal insufficiency were previously demonstrated as contributing factors to major bleeding in rivaroxaban patients [14]. Recently, glomerular filtration rates below $60 \mathrm{ml} / \mathrm{min}$ have been independently associated with higher-than-expected residual rivaroxaban levels in a perioperative setting [44]. This is not surprising since one third of the rivaroxaban dose is eliminated unchanged by the kidneys [25]. However, in our analysis, only two patients with moderate renal impairment had trough concentrations above the on-therapy range. Second, despite the highest convenience and fixed-dose regimen of DOAC, some of our patients did not receive the appropriate dose of rivaroxaban. In particular, one patient (No 9) was still taking rivaroxaban $15 \mathrm{mg}$ BID while the 21-day treatment phase of VTE had been completed. Yao and colleagues highlighted that patients with indication for dose reduction were often potentially overdosed, leading to an increased risk of major bleeding [19].

Drugs interactions with P-gp or CYP3A4 inhibitors were frequent in our patients, as previously reported [32, 45]. One patient (No 2) was taking diltiazem and clarithromycin, two inhibitors of both P-gp and CYP3A4. He had an estimated rivaroxaban level of $181 \mathrm{ng} / \mathrm{ml}$ at trough, exceeding the 95th percentile of the on-therapy range $(136 \mathrm{ng} / \mathrm{ml})$. In healthy volunteers, clarithromycin has been shown to promote a 2 -fold increase in rivaroxaban exposure [46]. Similarly, we extrapolated a rivaroxaban trough concentration of $125 \mathrm{ng} / \mathrm{ml}$ in a patient taking simvastatin (No 3). This P-gp inhibitor has been associated with a higher risk of major bleeding in patients taking dabigatran [47]. Pharmacodynamic interactions were also 
widely observed. Aspirin has often no valid indication in anticoagulated patients, while combination therapy has been shown to increase the risk of major bleeding $[16,48]$. A similar increase was associated with the addition of SSRIs, the most prescribed class of antidepressants [49].

An original aspect of this work was the investigation of several $A B C B 1$ polymorphisms. All 3 patients with higherthan-expected rivaroxaban levels and available genotyping data were at least heterozygous mutated for the $1236 \mathrm{C}>\mathrm{T}$, 2677G $>$ T, 3435C $>$ T and rs4148738 SNP. Previous experiments have shown that the $1236 \mathrm{~T}-2677 \mathrm{~T}-3435 \mathrm{~T}$ variant haplotype decreased $\mathrm{ABCB} 1$ expression or transport towards several drugs such as anticancer agents [50-52]. These results support our observations, as a decreased efflux of rivaroxaban may have led to drug accumulation. However, in a recent study conducted in 60 healthy volunteers, the $1236 \mathrm{~T}-2677 \mathrm{~T}-3435 \mathrm{~T}$ haplotype was not a significant determinant of rivaroxaban pharmacokinetics [46]. This strengthens the need for additional studies to clarify the impact of $A B C B 1$ polymorphisms on rivaroxaban transport. Indeed, our findings might also be due to the high frequency of the variant genotype $1236 \mathrm{~T}-2677 \mathrm{~T}-3435 \mathrm{~T}$ (up to $50 \%$ of the Caucasian population is expected to heterozygous mutated). Furthermore, these three patients were also receiving concomitant interacting medications, as previously discussed.

The study presents several limitations. First, statistical analysis was limited by the small number of plasma samples collected. However, this allowed an in-depth analysis of rivaroxaban measurements, including clinical, medication and genetic characteristics at the individual level. Second, three patients (No 24) were transfused with red blood cells (RBC) before sampling. For these patients, we cannot exclude that rivaroxaban measurements were not influenced by fluid volume or factor Xa content of packed RBC. However, Biophen ${ }^{\circ} \mathrm{DiXaI}$ was designed for minimizing the interference of plasma factors. Third, estimation of renal function was only based on serum creatinine on admission, as previous laboratory results performed in primary care were not available. Finally, the Pop PK model we used assumed no variability in the volume of distribution, while inter-individual variability in $\mathrm{V} / \mathrm{F}$ was $18 \%$ in another Pop PK model from AF patients [31]. However, simulations were previously performed and showed the limited influence of this variability on predicted exposure estimates.

\section{Conclusion}

In conclusion, rivaroxaban patients admitted to the ED for bleeding events showed highly variable plasma concentrations and a delayed elimination clearance. This underlines the usefulness of rapid DOAC measurement to assess contribution to the adverse event, manage urgent procedures or warrant antidote administration. Close patient follow-up, including renal function assessment and drug interactions review, is essential for bleeding risk minimization. Further studies are needed to investigate the impact of $A B C B 1$ polymorphisms on DOAC transport.

\section{Acknowledgements \\ A.L. Sennesael is a Research Fellow of the Fonds National de la Recherche Scientifique (FNRS). The authors would like to thank the emergency departments of the Cliniques Universitaires Saint-Luc and CHU UCL Namur, Pr F. Verschuren, Dr. X. Muschart, Mrs. J. Baudar, Mrs. M. Guldenpfennig for their contributions to this work. \\ Availability of data and materials \\ The datasets used and/or analysed during the current study are available from the corresponding author on reasonable request.}

\section{Authors' contributions}

$A L S, J D, J M D, A S$ and FM designed the research study. ALS and ASL contributed to plasma sample collection. LE, GS, MW, MT were responsible for the estimation of plasma concentrations at trough. ALS wrote the first draft of the manuscript and the final version. All authors read and approved the final manuscript.

\section{Ethics approval and consent to participate}

The study was approved by the Ethics Committees of the Cliniques Universitaires Saint-Luc (Brussels, Belgium) and the CHU UCL Namur (Yvoir, Belgium), and registered with clinicaltrials.gov (NCT02720328). Written informed consent was obtained from each patient.

Consent for publication

Not applicable.

\section{Competing interests}

The authors declare that they have no competing interests.

\section{Publisher's Note}

Springer Nature remains neutral with regard to jurisdictional claims in published maps and institutional affiliations.

\section{Author details}

'Louvain Drug Research Institute, Clinical Pharmacy Research Group, Université catholique de Louvain, Brussels, Belgium. ${ }^{2} \mathrm{CHU}$ UCL Namur, Namur Thrombosis and Hemostasis Center, Department of Pharmacy, Université catholique de Louvain, Yvoir, Belgium. ${ }^{3}$ Namur Research Institute for Llfe Sciences, Namur Thrombosis and Hemostasis Center, Department of Pharmacy, University of Namur, Namur, Belgium. ${ }^{4}$ Louvain Drug Research Institute, Integrated PharmacoMetrics, PharmacoGenomics and

PharmacoKinetics, Université catholique de Louvain, Brussels, Belgium. ${ }^{5}$ Center of Pharmacology, Therapeutic Drug Monitoring Unit, University Hospital of Cologne, Cologne, Germany. ${ }^{6}$ Center of Pharmacology, Clinical Pharmacology Unit, University Hospital of Cologne, Cologne, Germany. ${ }^{7} \mathrm{CHU}$ UCL Namur, Namur Thrombosis and Hemostasis Center, Hematology

Laboratory, Université catholique de Louvain, Yvoir, Belgium.

Received: 4 June 2018 Accepted: 21 August 2018

Published online: 12 November 2018

\section{References}

1. Turpie AG, Esmon C. Venous and arterial thrombosis--pathogenesis and the rationale for anticoagulation. Thromb Haemost. 2011;105:586-96.

2. Santos-Gallego CG, Bayon J, Badimon JJ. Thrombi of different pathologies: implications for diagnosis and treatment. Curr Treat Options Cardiovasc Med. 2010;12:274-91.

3. Shehab N, Lovegrove MC, Geller Al, Rose KO, Weidle NJ. Budnitz DS. US emergency department visits for outpatient adverse drug events, 20132014. JAMA. 2016;316:2115-25. 
4. Ruff CT, Giugliano RP, Braunwald E, Hoffman EB, Deenadayalu N, Ezekowitz $M D$, et al. Comparison of the efficacy and safety of new oral anticoagulants with warfarin in patients with atrial fibrillation: a meta-analysis of randomised trials. Lancet. 2014;383:955-62.

5. van Es N, Coppens M, Schulman S, Middeldorp S, Buller HR. Direct oral anticoagulants compared with vitamin $\mathrm{K}$ antagonists for acute venous thromboembolism: evidence from phase 3 trials. Blood 2014; 124:1968-1975.

6. Ntaios G, Papavasileiou V, Makaritsis K, Vemmos K, Michel P, Lip GYH. Realworld setting comparison of nonvitamin-K antagonist oral anticoagulants versus vitamin-K antagonists for stroke prevention in atrial fibrillation: a systematic review and meta-analysis. Stroke. 2017;48:2494-503.

7. Douxfils J, Ageno W, Samama CM, Lessire S, Ten Cate H, Verhamme P, et al. Laboratory testing in patients treated with direct oral anticoagulants: a practical guide for clinicians. J Thromb Haemost. 2018;16:209-19.

8. Eikelboom JW, Quinlan DJ, Hirsh J, Connolly SJ, Weitz Jl. Laboratory monitoring of non-vitamin $\mathrm{K}$ antagonist oral anticoagulant use in patients with atrial fibrillation: a review. JAMA Cardiol. 2017:2:566-74.

9. Reilly PA, Lehr T, Haertter S, Connolly SJ, Yusuf S, Eikelboom JW, et al. The effect of dabigatran plasma concentrations and patient characteristics on the frequency of ischemic stroke and major bleeding in atrial fibrillation patients: the RE-LY trial (randomized evaluation of long-term anticoagulation therapy). J Am Coll Cardiol. 2014;63:321-8.

10. Ruff CT, Giugliano RP, Braunwald E, Morrow DA, Murphy SA, Kuder JF, et al. Association between edoxaban dose, concentration, anti-factor Xa activity, and outcomes: an analysis of data from the randomised, double-blind ENGAGE AF-TIMI 48 trial. Lancet. 2015;385:2288-95.

11. Testa S, Paoletti O, Legnani C, Dellanoce C, Antonucci E, Cosmi B, et al. Low drug levels and thrombotic complications in high-risk atrial fibrillation patients treated with direct oral anticoagulants. J Thromb Haemost. 2018;16:842-8.

12. Pollack CVJ, Reilly PA, van Ryn J, Eikelboom JW, Glund S, Bernstein RA, et al. Idarucizumab for dabigatran reversal — full cohort analysis. N Engl J Med. 2017. https://doi.org/10.1056/NEJMoa1707278.

13. Bouget J, Oger E. Emergency admissions for major haemorrhage associated with direct oral anticoagulants. Thromb Res. 2015;136:1190-4.

14. Beyer-Westendorf J, Forster K, Pannach S, Ebertz F, Gelbricht V, Thieme C, et al. Rates, management, and outcome of rivaroxaban bleeding in daily care: results from the Dresden NOAC registry. Blood. 2014;124:955-62.

15. Camm AJ, Amarenco P, Haas S, Hess S, Kirchhof $P$, Kuhls $S$, et al. XANTUS: a realworld, prospective, observational study of patients treated with rivaroxaban for stroke prevention in atrial fibrillation. Eur Heart J. 2016;37:1145-53.

16. Shah R, Hellkamp A, Lokhnygina Y, Becker RC, Berkowitz SD, Breithardt G, et al. Use of concomitant aspirin in patients with atrial fibrillation: findings from the ROCKET AF trial. Am Heart J. 2016;179:77-86.

17. Washam JB, Hellkamp AS, Lokhnygina Y, Piccini JP, Berkowitz SD, Nessel CC, et al. Efficacy and safety of rivaroxaban versus warfarin in patients taking Nondihydropyridine Calcium Channel blockers for atrial fibrillation (from the ROCKET AF trial). Am J Cardiol. 2017;120:588-94.

18. Whitworth MM, Haase KK, Fike DS, Bharadwaj RM, Young RB, MacLaughlin EJ. Utilization and prescribing patterns of direct oral anticoagulants. Int J Gen Med. 2017;10:87-94.

19. Yao X, Shah ND, Sangaralingham LR, Gersh BJ, Noseworthy PA, Non-Vitamin K. Antagonist oral anticoagulant dosing in patients with atrial fibrillation and renal dysfunction. J Am Coll Cardiol. 2017:69:2779-90.

20. Ing Lorenzini K, Daali Y, Fontana P, Desmeules J, Samer C. Rivaroxabaninduced hemorrhage associated with $A B C B 1$ genetic defect. Front Pharmacol. 2016;7:494

21. Sennesael AL, Larock AS, Devalet B, Mathieux V, Verschuren F, Muschart X, et al. Preventability of serious thromboembolic and bleeding events related to the use of oral anticoagulants: a prospective study. Br J Clin Pharmacol. 2018;84:1544-56.

22. Gouin-Thibault I, Freyburger G, de Maistre E, Susen S, Delavenne X, Golmard $J$, et al. Evaluation of dabigatran, rivaroxaban and apixaban target-specific assays in a multicenter French study. Thromb Res. 2017;158:126-33.

23. Lessire S, Douxfils J, Pochet L, Dincq AS, Larock AS, Gourdin M, et al. Estimation of rivaroxaban plasma concentrations in the perioperative setting in patients with or without heparin bridging. Clin Appl Thromb Hemost. 2018;24:129-38.

24. Wiesen MHJ, Blaich C, Taubert M, Jennissen V, Streichert T, Pfister R, et al. Residual rivaroxaban exposure after discontinuation of anticoagulant therapy in patients undergoing cardiac catheterization. Eur J Clin Pharmacol. 2018;74:611-8.
25. Mueck W, Stampfuss J, Kubitza D, Becka M. Clinical pharmacokinetic and pharmacodynamic profile of rivaroxaban. Clin Pharmacokinet. 2014;53:1-16.

26. Hanlon JT, Schmader KE, Samsa GP, Weinberger M, Uttech KM, Lewis IK, et al. A method for assessing drug therapy appropriateness. J Clin Epidemiol. 1992;45:1045-51.

27. Larock AS, Mullier F, Sennesael AL, Douxfils J, Devalet B, Chatelain C, et al. Appropriateness of prescribing dabigatran etexilate and rivaroxaban in patients with nonvalvular atrial fibrillation: a prospective study. Ann Pharmacother. 2014;48:1258-68.

28. Wang Y, Kong MC, Ko Y. Psychometric properties of the 8-item Morisky medication adherence scale in patients taking warfarin. Thromb Haemost. 2012;108:789-95.

29. Gulilat M, Tang A, Gryn SE, Leong-Sit P, Skanes AC, Alfonsi JE, et al. Interpatient variation in rivaroxaban and Apixaban plasma concentrations in routine care. Can J Cardiol. 2017:33:1036-43.

30. Testa S, Tripodi A, Legnani C, Pengo V, Abbate R, Dellanoce C, et al. Plasma levels of direct oral anticoagulants in real life patients with atrial fibrillation: results observed in four anticoagulation clinics. Thromb Res. 2016;137:178-83.

31. Girgis IG, Patel MR, Peters GR, Moore KT, Mahaffey KW, Nessel CC, et al. Population pharmacokinetics and pharmacodynamics of rivaroxaban in patients with non-valvular atrial fibrillation: results from ROCKET AF. J Clin Pharmacol. 2014;54:917-27.

32. Albaladejo P, Samama CM, Sie P, Kauffmann S, Memier V, Suchon P, et al. Management of Severe Bleeding in patients treated with direct oral anticoagulants: an observational registry analysis. Anesthesiology. 2017;127:111-20.

33. Seiffge DJ, Kagi G, Michel P, Fischer U, Bejot $Y$, Wegener $S$, et al. Rivaroxaban plasma levels in acute ischemic stroke and intracerebral hemorrhage. Ann Neurol. 2018;83:451-9.

34. Steffel J, Verhamme P, Potpara TS, Albaladejo P, Antz M, Desteghe L, et al. The 2018 European heart rhythm association practical guide on the use of non-vitamin $\mathrm{K}$ antagonist oral anticoagulants in patients with atrial fibrillation. Eur heart J. 2018;39:1330-93.

35. Tomaselli GF, Mahaffey KW, Cuker A, Dobesh PP, Doherty JU, Eikelboom JW, et al. ACC expert consensus decision pathway on Management of Bleeding in patients on oral anticoagulants: a report of the American College of Cardiology Task Force on expert consensus decision pathways. J Am Coll Cardiol 2017. 2017;70:3042-67.

36. Connolly SJ, Milling TJ Jr, Eikelboom JW, Gibson CM, Curnutte JT, Gold A, et al. Andexanet alfa for acute major bleeding associated with factor $\mathrm{Xa}$ inhibitors. N Engl J Med. 2016;375:1131-41.

37. Andexxa-An Antidote for Apixaban and Rivaroxaban. JAMA. 2018;320:399-400.

38. Eerenberg ES, Kamphuisen PW, Sijpkens MK, Meijers JC, Buller HR, Levi M. Reversal of rivaroxaban and dabigatran by prothrombin complex concentrate: a randomized, placebo-controlled. crossover study in healthy subjects Circulation. 2011;124:1573-9.

39. Douxfils J, Mullier F, Loosen C, Chatelain C, Chatelain B, Dogne JM. Assessment of the impact of rivaroxaban on coagulation assays: laboratory recommendations for the monitoring of rivaroxaban and review of the literature. Thromb Res. 2012;130:956-66.

40. Van Blerk M, Bailleul E, Chatelain B, Demulder A, Devreese K, Douxfils J, et al. Influence of dabigatran and rivaroxaban on routine coagulation assays. A nationwide Belgian survey Thromb Haemost. 2015;113:154-64.

41. Douxfils J, Gosselin RC. Laboratory assessment of direct oral anticoagulants. Semin Thromb Hemost. 2017;43:277-90.

42. Seiffge DJ, Traenka C, Polymeris A, Hert L, Fisch U, Peters N, et al. Feasibility of rapid measurement of rivaroxaban plasma levels in patients with acute stroke. J Thromb Thrombolysis. 2017;43:112-6.

43. Dincq AS, Lessire S, Pirard G, Siriez R, Guldenpfennig M, Baudar J, et al. Reduction of the turn-around time for the measurement of rivaroxaban and apixaban: Assessment of the performance of a rapid centrifugation method. Int J Lab Hematol. 2018. https://doi.org/10.1111/ijlh.12870.

44. Kaserer A, Schedler A, Jetter A, Seifert B, Spahn DR, Stein P, et al. Risk factors for higher-than-expected residual rivaroxaban plasma concentrations in real-life patients. Thromb Haemost. 2018;118:808-17.

45. Jungbauer L, Dobias C, Stollberger C, Weidinger F. The frequency of prescription of P-glycoprotein-affecting drugs in atrial fibrillation. J Thromb Haemost. 2010;8:2069-70.

46. Gouin-Thibault I, Delavenne X, Blanchard A, Siguret V, Salem JE, Narjoz C, et al. Interindividual variability in dabigatran and rivaroxaban exposure: contribution of $A B C B 1$ genetic polymorphisms and interaction with clarithromycin. J Thromb Haemost. 2017;15:273-83. 
47. Antoniou T, Macdonald EM, Yao Z, Hollands S, Gomes T, Tadrous M, et al. Association between statin use and ischemic stroke or major hemorrhage in patients taking dabigatran for atrial fibrillation. CMAJ. 2017;189:E4-e10.

48. Hernandez I, Baik SH, Pinera A, Zhang Y. Risk of bleeding with dabigatran in atrial fibrillation. JAMA Intern Med. 2015;175:18-24.

49. Quinn GR, Singer DE, Chang Y, Go AS, Borowsky LH, Udaltsova N, et al. Effect of selective serotonin reuptake inhibitors on bleeding risk in patients with atrial fibrillation taking warfarin. Am J Cardiol. 2014;114:583-6.

50. Dessilly G, Panin N, Elens L, Haufroid V, Demoulin JB. Impact of ABCB1 $1236 \mathrm{C}>\mathrm{T}-2677 \mathrm{G}>\mathrm{T}-3435 \mathrm{C}>\mathrm{T}$ polymorphisms on the anti-proliferative activity of imatinib, nilotinib, dasatinib and ponatinib. Sci Rep. 2016;6:29559.

51. Salama NN, Yang Z, Bui T, Ho RJ. MDR1 haplotypes significantly minimize intracellular uptake and transcellular P-gp substrate transport in recombinant LLC-PK1 cells. J Pharm Sci. 2006;95:2293-308.

52. Hoffmeyer S, Burk O, von Richter O, Arnold HP, Brockmoller J, Johne A, et al. Functional polymorphisms of the human multidrug-resistance gene: multiple sequence variations and correlation of one allele with Pglycoprotein expression and activity in vivo. Proc Natl Acad Sci U S A. 2000; 97:3473-8.

Ready to submit your research? Choose BMC and benefit from:

- fast, convenient online submission

- thorough peer review by experienced researchers in your field

- rapid publication on acceptance

- support for research data, including large and complex data types

- gold Open Access which fosters wider collaboration and increased citations

- maximum visibility for your research: over $100 \mathrm{M}$ website views per year

At $\mathrm{BMC}$, research is always in progress.

Learn more biomedcentral.com/submissions 